\title{
十二指腸潰瘍穿孔部に印環細胞癌とアニサキス虫体様構造
}

\section{を思わせる異物をみた 1 症例}

\begin{tabular}{|c|c|c|c|c|c|c|}
\hline \multicolumn{7}{|c|}{ 同 病理* } \\
\hline 平田 & 展章 & 金 & 昌雄 & 前田 & 克昭 & 西山 \\
\hline 赤松 & 大樹 & 北川 & 晃 & 岡野 & 錦弥 & \\
\hline
\end{tabular}

\section{A CASE OF PERFORATED DUODENAL ULCER, IN WHICH OBSERVED SINGET RING CELL CARCI NOMA AND ANISAKIS LIKE LARVA}

\section{Nobuaki HIRATA, Masao KIM, Katsuaki MAEDA, Makoto NISHIYAMA, Hiroki AKAMATSU, Akira KITAGAWA and Kinya OKANO*}

Department of Surgery and *Pathology, Osaka Police Hospital

索引用語：十二指腸潰瘍穿孔，アニサキス症, 印環細胞癌

はじめに

われわれは，臨床的に十二指腸潰瘍の急性穿孔を示 した症例で，病理組織学的に潰瘍前縁部より幽門輪に 達する印環細胞癌と一見アニサキス虫体様構造物およ びその他の寄生虫の虫畉様構造物の存在を見たので， これらの病変について臨床病理学的に考察を加兄報告 する.

\section{症例}

患者：45歳, 男性, 会社員。

主訴：心窩部痛。

既往歴・家族歴：特記すべきことなし。

現病歴：昭和 60 年 11 月 12 日頃, 空腹時心窩部痛を自 覚するようになった。11月17日，心窩部に激痛出現し 近医受診。経過観察するも軽快しないため，翌日胃透 視施行. 十二指腸潰瘍穿孔の診断のもと，当科紹介さ れ受診。な扣発症 1 週間以内に生鮮魚介類の摂取はな い.

現病：体格中等度，栄養状態良好。貧血・黄疸は認 めない，胸部理学的所見に異常を認めないが，腹部は 心窝部から右季肋部にかけて著明な筋性防御を伴う圧 痛を認めた。肝脾掞よび腫瘤は触知しなかった，四肢 に異常なく表在リンパ節は触知しなかった。

検査所見：検血では, 白血球 $12,700 / \mathrm{mm}^{3}$ と上昇し 核の左方移動を認めた。生化学的検查では T. Bil 1.7 $\mathrm{mg} / \mathrm{dl}$ と軽度上昇を示すほかは, 肝腎機能を含め異常

$<1988$ 年 2 月 10 日受理 $>$ 別刷請求先: 平田 展章 干543 大阪市天王寺区北山町10-31 大阪警察病院 外科
を認めなかった。 $\alpha$-fetoprotein は3ng/ml, carcinoembryonic antigen は1.0ng/ml と正常であった. 胸部 X 線写真では，右横隔膜下に遊離ガス像を認めた。また 胃透視にて，十二指腸第 1 部前壁に潰晹を認めたが, 明らかな造影剂の漏出を認めなかった。 以上の所見に より，同日緊急手術を施行した。

手術所見：上腹部正中切開にて開腹。腹水は認めな かった，右上腹部では，大網および肝円索が集合し， 十二指腸第 1 部付近を被っていた，同部に少量の膿苔 を認めた。これらの組織を㕷離し，十二指腸第 1 部を 観察すると幽門輪より約 $1 \mathrm{~cm}$ 肛門側の前壁に大きさ $2 \times 3 \mathrm{~mm}$ の穿孔を認めた。悪性所見は認められず，典 型的な十二指腸潰瘍穿孔の像を呈していた。幽門側胃

図 1 肉眼的組織所見. 十二指腸第 1 部前壁に陳旧性 の潰場を認め，その内部に大きさ $2 \times 3 \mathrm{~mm}$ の穿孔を 認める。明らかな悪性所見はない。
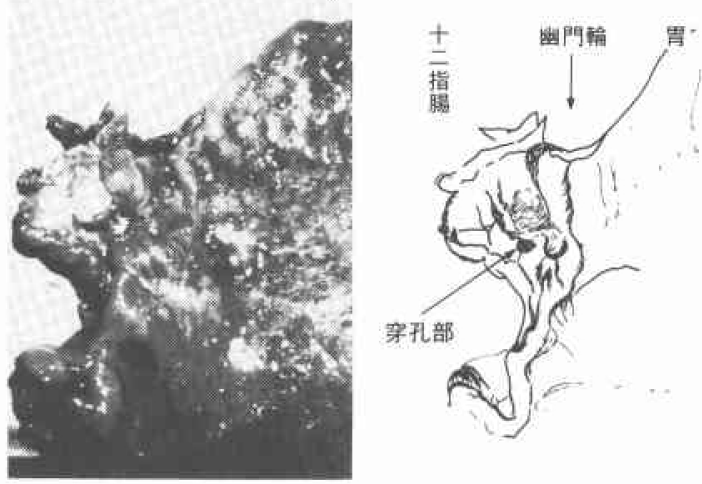
図2 全割連続切片を図示する。図に示す部位に, 印環細胞癌およびアニサキス虫体 様構造物（亀甲様構造物，消化管上皮様断片）・他の寄生虫卵様構造物を認める.
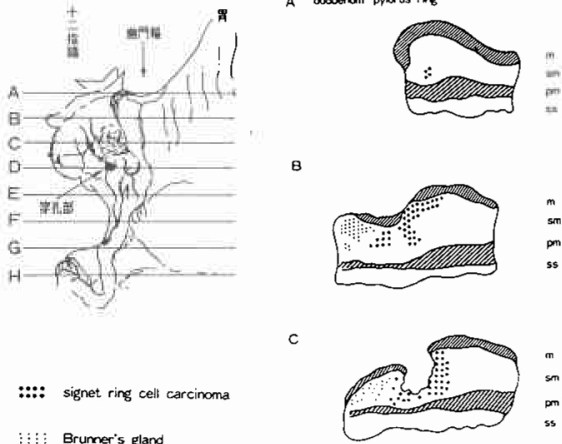

: : : : Brumer's gland

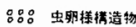

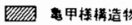

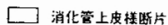

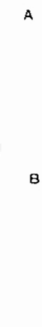

$c$

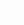
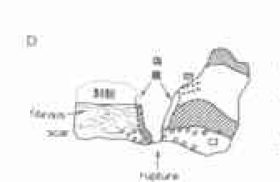
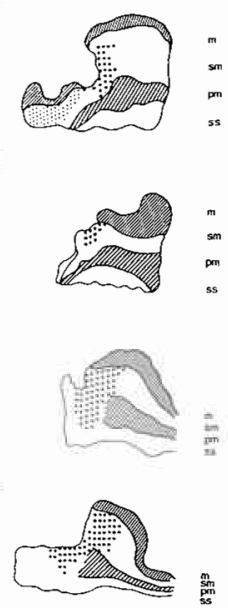

図 3 印環細胞癌の組織学的所見.

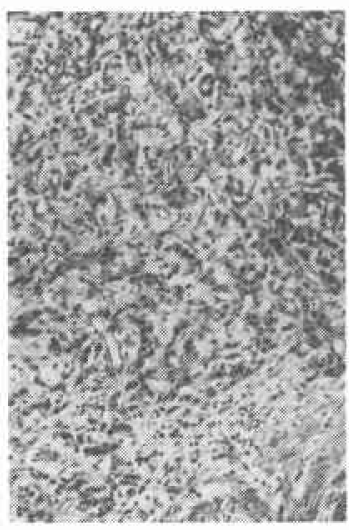

$\times 100$

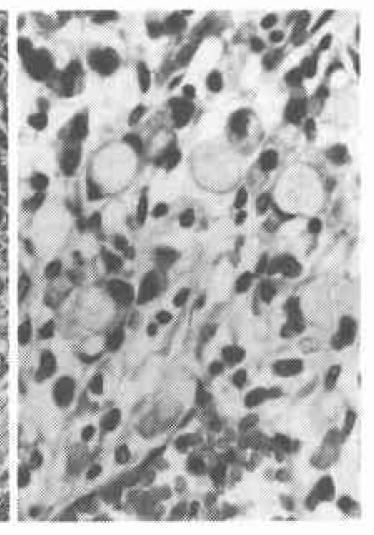

$\times 400$

切除術を施行し，Billroth I 法にて再建した。

病理所見：肉眼的には, 幽門輪より約 $1 \mathrm{~cm}$ 肛門側の 十二指腸第 1 部前壁に大きさ $2 \times 3 \mathrm{~mm}$ の穿孔を伴 5 潰 瘍を認めた。同部はやや疲痕性に変形しており，潰瘍 は幾分陳旧性であることを思わせ，一見悪性所見は認 められなかった(図1).しかし組織学的所見では, 全 割連続切片において, 印環細胞癌がその潰瘍壁の主と してロ側に, 穿孔部付近潰瘍底部では肚門側にも漫潤 していた。深達度はssであった（図 2，3）

また本症例に执いて以下に示す寄生虫様構造物の存 在を認めた（図 2,4 ).（a）潰瘍部粘膜付近に存在す るアニサキス消化管の構築に類似する亀甲様構造物,

（b）潰瘍部漿膜付近に存在するアニサキス消化管上
図 4 アニサキス虫体様構造物および他の寄生虫の虫 卵様構造物の組織学的所見.

（a）：アニサキス虫体表層部の構築に類似する亀甲 様造物，（b）：アニサキス消化管上皮様断片，（c）: 楕円または卵円形の虫卵様の構造物，(a')(b')：他 院で得られたアニサキス虫体

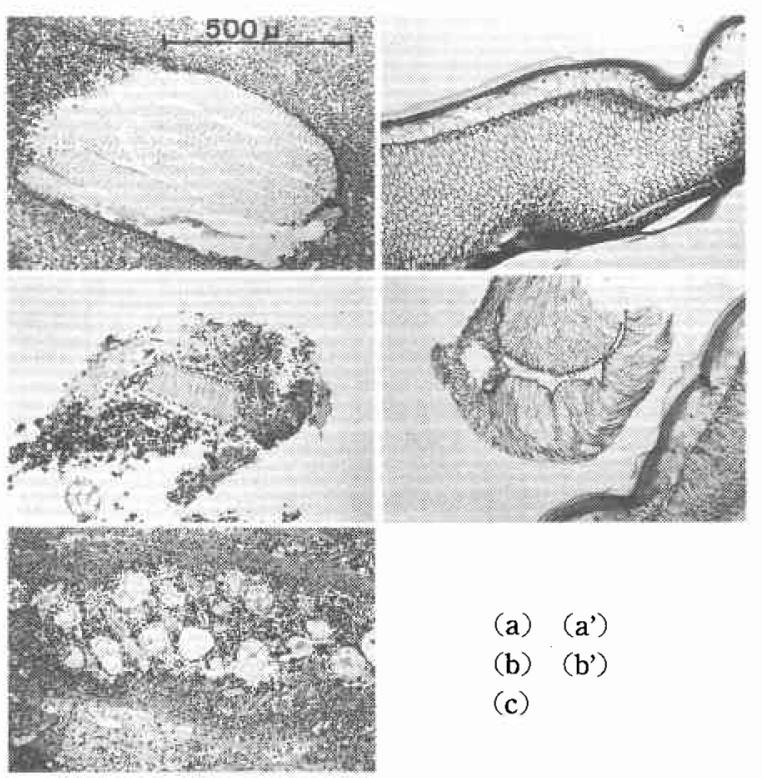

皮様断片，（c）潰瘍粘膜より潰瘍穿孔部の漿膜部の肉 芽層に多数存在する起源不明の径 $100 \mu \mathrm{m}$ 前後の棈円 または卵円形の虫卵样構造物である。

術後経過：以上の病理所見を得て, 初回手術より 1 
表 1 十二指腸に認められた印環細胞癌症例

\begin{tabular}{|c|c|c|c|}
\hline $\begin{array}{l}\text { 症例 } \\
\text { (1) 吉谷5 } \\
1968\end{array}$ & $\begin{array}{l}\text { 部 位 } \\
\text { 第 } 1 \text { 部 }\end{array}$ & $\begin{array}{c}\text { 型 } \\
\text { 陷凹型 }\end{array}$ & $\begin{array}{c}\text { 治磨法 } \\
\text { 胃切(B.I) }\end{array}$ \\
\hline $\begin{array}{l}\text { (2) 冧田5 } \\
1981\end{array}$ & 上十二指踼曲 & 山田 II 型 & ボリベクトミー \\
\hline $\begin{array}{l}\text { (3) 本 例 } \\
1985\end{array}$ & 第 1 部 & 陌凹型 & 胃切 (B・II) \\
\hline
\end{tabular}

カ月後の12月19日, 再手術を施行し Billroth II 法にて 再建した $\left(\mathrm{P}_{0} \mathrm{H}_{0} \mathrm{n}(-) \mathrm{R}_{2}\right)$. 前回手術切除部の口側お よび肛門側断端において, 悪性所見は得られなかった。 再手術後の経過は良好で再発兆候はない。なお術後頻 回の便の集卵検查を施行するも，寄生虫卵などは認め られなかった。杰た好酸球の増加も認められなかった。 免疫学的検査は発見の時期が遅れたため施行していな W.

\section{考察}

本症例の問題点としては，まず第一に十二指腸原発 癌の可否についてである。本例の原発巣の断定は必ず しも容易ではないが，潰瘍が明らかに十二指腸第 1 部 に存在し, 癌増殖の多くはその口側に強いも, 一部は 肛門側にも存在しており，可能珄として十二指腸原発 が示唆される。原発性十二指腸癌の頻度は, 剖検例で $0.1 \%$ 前後 ${ }^{1)}$, 手術例や臨床例に沶いて全消化管癌中 $0.37^{2)}-0.59^{3)} \%$ と極めて末れである。発生部位は乳頭 上部, 乳頭部, 乳頭下部に分類されるが, 乳頭部に関 しては原発部位が不明確の為除外されることが多い。 乳頭上部と下部の発生頻度は汪ぼ同じである。組織学 的には腺癌が玨倒的に多く，綿引ら をしめる．本症例のごとく印環細胞癌の報告例は少な く，われわれの調べえた限りでは本邦では2 例の報告

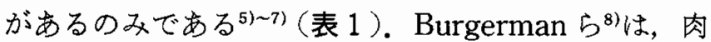
眼的形態について，（1）ulcering type, (2) polypoid type, (3) annular constricting type, (4) diffuse infiltrating typeに分類しているが，本邦に扣いては （1）(2)が大部分である. 治療法は外科的切除が主体で あり，以前は乳頭上部では胃切除術が，乳頭下部では 十二指腸部分切除が多く行われてきたが，最近では早 期癌を含め膵頭十二指腸切除が施行される傾向にあ

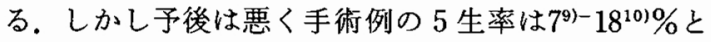
報告されている. 本症例は穿孔していることもあり根 治性の意味を考光, 十二指腸部分切除を加えた。

次に本症例のアニサキス虫体様構造を示す物体につ いてであるが, 複数の寄生虫専門家に意見を求めたと ころ，多くは食物残渣等の異物ではないかとい5意見 であった，しかしアニサキス虫体との意見もあり，ア ニサキス虫体による消化管穿孔の可能性も否定しえな
い、また他院で確認されたアニサキス虫体と非常によ く類似して扣り(図4),以下アニサキス症について述 ベる.

アニサキス症は，1960年 van Thiel ら て報告された比較的新しい寄生虫疾患である。水産国 であり海産魚類の生食が多くなされる本邦での報告は 近年増加の傾向にあり，石倉ら ${ }^{12)}$ の1980年までの全国 集計で1,823例と報告されている。本症例では，病理組 織学的にアニサキス症との確診はえられなかったが， 他院で確認されたアニサキス症と非常によく類似して いる(図 4).アニサキス第 3 期幼虫が非適合宿主であ るヒトの主として消化管に侵入することにより生じる 内臓幼虫䔟行症であるが，その発生機序として，消化 管穿入の機械的刺激とともに，アレルギー反応が重視 され，再感作の際には激烈な症状が生じる，免疫学的 研究により，現在 $\operatorname{IgE} に$ 対して診断的意義が見いださ れている(3).アニサキス症の発生部位は, 胃が圧倒的に

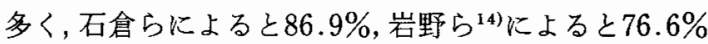
を占め，その穿入部位は胃内に広く分布しているが， 体部・大弯側に多い．腸では回腸が王倒的に多く，岩 野らは71.4\%と報告して和り，回腸全域にわたってい る。空腸・大腸はそれぞれ $10 \%$ 前後である．本例に認 められるごとく，十二指腸とくに第 1 部に認められた 症例は極めて少なく，長堂ら ${ }^{15)}$ が 1 例報告しているほ か，岩野らが十二指腸として 1 例報告している（消化 管全体の $0.7 \%$ ）。充矢崎らが，ときに十二指腸第 1 部に虫体がいたこともあると述べているのみである。

アニサキスと潰瘍の合併は, 以前は潰瘍があればア ニサキスが穿入しやすいと考它られたが今日では合併 は少ないとされている，アニサキスが潰瘍を形成する ことは, Sawaguchi ら ${ }^{16)}$ が言うようにまれであるが認 められることもある。

アニサキスと癌の同部位合併は，過去 2 例の報告が あるのみである17)18)(表 2). 全くの偶然に合併したと 思われるが, Tsutsumi ら ${ }^{18)}$ は癌により局所の免疫状 態が悪化したためである可能性す示唆している. アニ サキスが原因で癌が発生するには時間的関係より考え がたい.

本症例の穿孔は癌のためと考えられるが, 寄生虫体 様構造物の存在部位により，それがもし虫体であれば それも穿孔の要因に加わった可能性はある.アニサキ スによる消化管穿孔も多く報告されている ${ }^{19}$ (表 3 ). 異所寄生の診断は極めて困難であり, 術後の病理学的 検査によって初めて証明されることが多い.アニサキ スの穿孔に関して多くの動物実験がなされており，動 物においてはヒトより穿孔しやすいと考学られてい 
表 2 アニサキスと癌合併症例

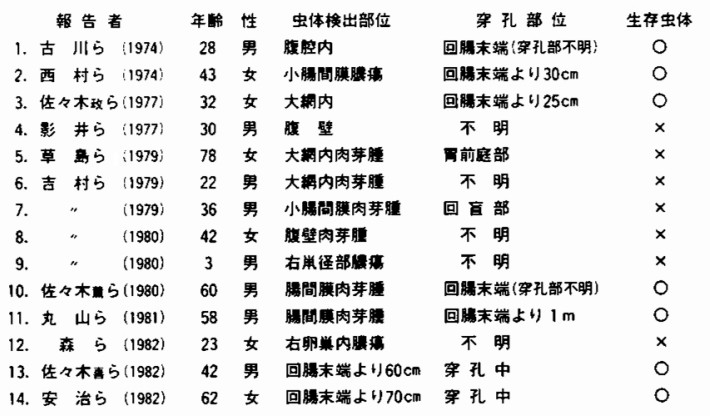

表 3 本邦における腸管外アニサキ、应（消化管穿孔 例)

\begin{tabular}{|c|c|c|c|}
\hline 報告 者 & 患 者 & 部 & アニサキスの存在竦位 \\
\hline $\begin{array}{l}\text { 1. 부도 } \\
\text { (1970) }\end{array}$ & 68男 & 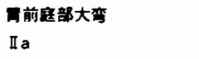 & 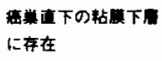 \\
\hline $\begin{array}{c}\text { 2. Tsutsumi b } \\
(1983)\end{array}$ & 73男 & $\begin{array}{l}\text { 足体部前壁 } \\
\text { Ic adenocarcinoma }\end{array}$ & 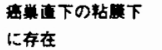 \\
\hline 3. 本症例 & 45城男 & 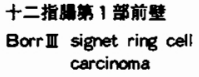 & 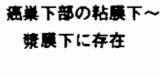 \\
\hline
\end{tabular}

$ð^{20)}$.

症状は, 胃では摂取後 6 〜数時間内に心裔部痛, 悪 心, 嘔吐で発症することが多い. 腸アニサキス症では 胃より発症時期が遅れて，1〜5 日後に突然の腹痛で 発症することが多い. 他に嘔気, 嘔吐, 下痢などが認 められる。

治療としては, 胃に関しては, 他の急性腹症との鑑 別が困難であり，問診にて疑われるならぱ，緊急内視 鐘にて虫体摘出を試みられるべきである，腸では鑑別 が胃以上に困難であり，問診を重視し，アニサキスな らばその虫体は約 1 週間で死隇するため, 対症療法で 軽快することが多い. しかし敛重な管理が必要である ことは言うまでもない.

また起源不明の楕円形・卵円形の虫卵様構造物に対 しては, 本態不明の異物との意見が多く今後の検討が 必要である。

$$
\text { まとめ }
$$

十二指腸穿孔部に, 印環細胞癌と一見アニサキス虫 体を思わせる構造物および他の寄生虫の虫卵様構造物 を認めた極めてまれな 1 例を経験したので報告した。

$$
\text { 文献 }
$$

1）若林泰文, 村山久夫, 小島豊雄注か：色素染色法併 用払大内視鏡が有用であった早期十二指腸癌の一 例. Gastroenterol Endosc 26:447-462, 1984

2) 成井 貴, 竹腰隆男, 杉山憲義はか：原発性十二指
腸癌（第一部）の一例. Prog Dig Endsc 13：194 -198, 1978

3）佐藤寿雄, 木村俊一, 佐久間晃注か：十二指腸性腫 湯について。外科 $32: 281-287,1970$

4）綿引 元, 中野 哲, 武田 功泳：原発性十二指 腸癌の一例。胃之腸 $14: 827-832,1979$

5）吉谷和男, 高橋秀夫, 吉村晃治注か：十二指腸球部 早期癌の一例. Gastroenterol Endosc 10:232 $-235,1968$

6）森田敏和, 川瀨健夫，上井一男ほか：十二指腸球後 部早期癌の一例. Prog Dig Endosc 19:230-233, 1981

7) Larsen E, Johansen A: Primary superficial carcinomas of the duodenum. Acta Pathol Microbiol Scand 26 : 487-494, 1968

8) Burgerman A, Baggenstoss AM, Cain JC: Primary malignant neoplasms of the duodenum excluding the papilla of vater. Gastroenter. ology $30: 421-431,1956$

9) Nakase A, Matsumoto $Y$, Uchida $K$ et al : Surgical treatment of cancer of the pancreas and the periampullary region. Ann Surg 185: 52-57, 1977

10) Alwmark A, Andersson A, Lasson A: Primary cancer of the duodenum. Am J Surg 141 : $13-18,1981$

11) van Thiel PH, Kuipers FC, Roskam R Th : A nematode parasitic to herring causing acote abdominal syndrome in man. Trop Geogr Med $12: 97-115,1960$

12）石倉 繁, 菊池世布子, 石倉 浩：アニサキス幼虫 に上る急性腸炎。胃と腸 $18 ： 393-397,1983$

13）竹本裕美, 过 守康：Enzyme Linked Immunosorbent Assay によるアニサキス幼虫粗抗 原特異 IgE抗体の検出. フレルギー $34: 403-$ 410,1985

14）岩野英明, 石倉 肇, 早坂 晃：最近 5 か年間に発 生したわが国に扣ける了二サキス症の疫学的研 究. 外科診療 $16: 1336-1342,1974$

15）長堂朝生, 仲西常雄, 長谷川英男ほか：当院にて経 験した十二指腸不部了ニサキス塵の一例。沖繩医 会誌 $21: 448-449,1984$

16) Sugimachi $K$, Inokuchi $K$, Ooiwa $K$ et al : Acute gastric anisakiasis. Analysis of 178 cases. JAMA 253: 1012-1013, 1985

17）早川光久, 鈴木健二, 前多豊吉ほか：好酸球肉芽腫 に伴った早期胃癌 (IIa). 胃と腸 5：223-227, 1970

18) Tsutsumi $Y$, Fujimoto $Y$ : Early gastric cancer superimposed on infestation of an anisakislike laverva : A case report. Tokai J Exp Clin Med $8: 265-273,1983$

19）吉村裕之, 赤尾信明, 近藤力王至ほか：アニサキス 幼虫の消化管外寄生 (異所)の2 症例とその免疫診 㷌について. 臨病理 28:708-712, 1980

20) Asami K, Inoshita $Y$ : Experimental anisakiasis in guinea pigs: Facter influencing infection of larvae in the host. Jpn J Parasit 16: $415-422,1967$ 